\title{
«Extranjeras»: Citizenship and Women Serving Drug Trafficking Sentences in the Santa Monica Prison
}

«Extranjeras»: ciudadanía y mujeres cumpliendo condenas de tráfico de drogas en el penal Santa Mónica

«Extranjeras»: citoyenneté et femmes purgeant une peine pour trafic de drogue dans le pénitencier Santa Monica

\section{Stephanie Campos}

\section{OpenEdition}

\section{Journals}

Electronic version

URL: https://journals.openedition.org/bifea/4340

DOI: $10.4000 /$ bifea. 4340

ISSN: 2076-5827

\section{Publisher}

Institut Français d'Études Andines

Printed version

Date of publication: 1 May 2014

Number of pages: 75-91

ISSN: 0303-7495

\section{Electronic reference}

Stephanie Campos, "«xtranjeras»: Citizenship and Women Serving Drug Trafficking Sentences in the Santa Monica Prison", Bulletin de l'Institut français d'études andines [Online], 43 (1) | 2014, Online since 08 May 2014, connection on 21 September 2021. URL: http://journals.openedition.org/bifea/4340 ; DOl: https://doi.org/10.4000/bifea.4340

\section{(c) (†) $\odot$}

Les contenus du Bulletin de l'Institut français d'études andines sont mis à disposition selon les termes de la licence Creative Commons Attribution - Pas d'Utilisation Commerciale - Pas de Modification 4.0 International. 


\title{
«Extranjeras»: Citizenship and Women Serving Drug Trafficking Sentences in the Santa Monica Prison
}

\author{
Stephanie Campos*
}

\begin{abstract}
This paper is based on research in the Establecimiento Penitenciario Mujeres de Chorrillos in Lima, Peru. I will analyze how citizenship intersects with race and gender inside the prison in order to limit or make available access to resources. Incarcerated non-Peruvians serving sentences for drug trafficking are the focus of this paper. Although the women included in this paper were all extranjeras, their citizenship status, combined with other positionalities, influenced their access to resources in multiple ways. Citizenship Is also a key factor in structuring relationships between foreign and Peruvian prisoners and the resulting hierarchy of this prison.
\end{abstract}

Keywords: citizenship, incarceration, cocaine, foreign prisoners

\section{«Extranjeras»: ciudadanía y mujeres cumpliendo condenas de tráfico de drogas en el penal Santa Mónica}

\section{Resumen}

Este documento se basa en la investigación en el Establecimiento Penitenciario de Mujeres de Chorrillos, en Lima, Perú. Se analizará cómo la ciudadanía se cruza con la raza y el género dentro de la prisión con el fin de limitar o facilitar el acceso a los recursos disponibles. Las no peruanas encarceladas que cumplen condenas por tráfico de drogas son el foco de este artículo. Aunque todas las mujeres incluidas en este estudio son extranjeras, su estado de ciudadanía, junto con otros posicionamientos, influye de múltiples maneras en su acceso a los recursos. La ciudadanía también es un factor clave en

PhD in Anthropology Investigator, National Development and Research Institutes, Inc., 71 West 23rd Street, New York, NY 10010. E-mail: campos@ndri.org 
la estructuración de las relaciones entre las presas extranjeras y peruanas y la jerarquía resultante de esta prisión.

Palabras clave: ciudadanía, encarcelamiento, cocaína, presas extranjeras

\section{«Extranjeras»: citoyenneté et femmes purgeant une peine pour trafic de drogue dans le pénitencier Santa Monica}

\section{Résumé}

Ce document est basé sur des recherche faites au pénitencier de Chorrillos, Lima, Pérou. L'auteure propose d'analyser comment l'intersection de la citoyenneté, de la race et du sexe dans la prison limite ou facilite l'accès aux ressources disponibles. Ce sont les non péruviennes qui purgent une peine pour trafic de drogue qui font l'objet de cet article. Bien que toutes les femmes de cette étude soient étrangères, le statut lié à la citoyenneté, ainsi que d'autres facteurs, peuvent influencer de plusieurs façons leur accès aux ressources. La citoyenneté est également un facteur-clé dans la structuration des relations entre les prisonnières étrangères et péruviennes, et la hiérarchie qui en découle dans cette prison.

Mots-clés: citoyenneté, incarcération, cocaïne, détenues étrangères

\section{INTRODUCING THE SANTA MONICA PRISON}

This paper will analyze the role of citizenship in stratifying the Establecimiento Penitenciario de Mujeres de Chorrillos (commonly referred to by its previous name, Santa Monica) in Lima, Peru. I will focus on four non-Peruvian prisoners who were serving sentences for drug trafficking during the time of my fieldwork in 20082009. They are: Linda, originally from Romania but a holder of Swiss citizenship; Ada, a Spanish national; Leslie, a Malaysian citizen; and finally, Paloma, a Bolivian mother who lived with her daughter inside the prison.

Santa Monica is an innocuous flat green building sitting on the edge of a wide and busy avenue in Lima. It is surrounded by restaurants, grocery stores, internet cafes and homes. Past one of the inside gates of the prison is where the prison population lives. A large open-air patio is the center of activity. It is surrounded by the administration wing, chapel, beauty salon, nursery, clinic, auditorium and one of the dormitory buildings. On the opposite end of this patio is another gate where the three dormitory buildings are located. A guard stands in front of this gate. These dormitory buildings surround two smaller patios. I spent most of my time speaking with women in the main patio. On a typical day it is full of women walking, knitting, doing nails or hair, talking, gossiping, people watching and waiting for their turns to speak with a staff person or with their lawyers. A couple of women from the bakery workshop walk around selling empanadas. Another woman sits on a bench selling instant coffee or soda, depending on the weather. 
Some women hold infants in their arms but most of the children spend their days in the nursery. About fifty children under the age of three live in the prison with their mothers. The phones are also located in the main patio. These eight public phones only accept calling cards or coins and long lines form during the hours women are allowed to make phone calls. A guard or two walk around observing the women but for the most part, only a handful of guards can be seen in the patio. On a warm sunny day this area can get very crowded.

Santa Monica was built in 1952 as a reformatory to hold 300 women, but during the time of my fieldwork in 2008-2009, it held more than three times its capacity. In August 2010, there were 2753 women incarcerated in Peruvian prisons (INPE, 2010). This number had grown to 3640 by June 2012 (INPE, 2012). This is still small in comparison to the number of imprisoned men who number about 42000. But women are overwhelmingly put into prison for drug related crimes whereas most men are in prison on charges of violent crimes. According to reports by INPE, between sixty to seventy percent of these women were arrested on charges of drug trafficking. They had been accused of either selling cocaine, transporting it within Peru and/or Lima, belonging to a drug trafficking organization, or smuggling cocaine into a male prison.

Of the about nine-hundred women incarcerated in Santa Monica in 2008, approximately one-hundred were not Peruvian and came from countries such as Malaysia, Spain, South Africa, the Netherlands, Poland, the United States and the Philippines. Many had arrived not knowing any Spanish but they quickly learned how to speak and read it, as the prison did not offer any translation services. Mostly they kept to themselves and formed friendships with women of similar nationalities and languages. Foreign prisoners in Santa Monica ranged from young women in their twenties to a few who were in their late fifties and early sixties. They represented a variety of ethnicities and racial backgrounds. Almost all of them had been caught attempting to carry cocaine out of Peru's main airport. Some had been caught with cocaine inside the city borders.

Figure 1 - Number of Incarcerated Foreign Females by Region

\begin{tabular}{|c|c|}
\hline Region & $\begin{array}{c}\text { Number of foreign women in } \\
\text { peruvian prisons }\end{array}$ \\
\hline Africa & 12 \\
\hline Asia & 40 \\
\hline America & 106 \\
\hline Europe & 92 \\
\hline Oceania & 1 \\
\hline
\end{tabular}

Source: INPE (2012) 


\section{BACKGROUND}

This prison brings together foreign and Peruvian workers of the transnational cocaine commodity chain (TCCC). This is a conceptual framework that understands cocaine as a commodity that moves across nation-states and «as an end product of global commodity chain» (Wilson \& Zambrano, 1994: 297). This paper will focus on the foreign prisoners, that in, non-Peruvian women who were arrested on drug trafficking charges. I will explore how citizenship was important in Santa Monica as it unevenly granted rights, privileges and means of obtaining life dependent resources among prisoners. Like Kipnis, I argue for the use of this concept «as an independent axis for the analysis of both social differences and inequality» (Kipnis, 2004: 258). For example, it contributed to reproducing globalized inequalities inside this local prison. For the sake of clarity, citizenship rather than nationality will be used when addressing global inequities among women in Santa Monica. McCrone \& Kiely state that nationality and citizenship «belong to different spheres of meaning and activity» (McCrone \& Kiely, 2000: 25). Nationality is a «cultural concept which binds people on the basis of shared identity... while citizenship is a political concept deriving from people's relationship to the state» (McCrone \& Kiely, 2000: 25). It also affected other social categories inside the prison.

This study uses an intersectional methodology. Through its application, I discovered that race, gender, class and citizenship were separate projects inside Santa Monica but that they also mutually shaped each other at the point of intersection (Walby, 2012) and this had consequences for how women survived incarceration. Inequality was produced and reproduced inside Santa Monica through the interconnection of these categories. There was some renegotiation in the daily remaking of disparity and uneven access to resources. Ultimately however these social categories, especially citizenship, interacted in ways that stratified the prison population. Multiple divisions among the women ended up mirroring national and globalized structural inequalities.

An intersectional analysis is useful in tracing how these categories relate to one another and how they became rearranged. This framework became an important form of analysis in feminist research with Crenshaw's discussion of «how the experiences of women of color are frequently the product of intersecting patterns of racism and sexism» (Crenshaw, 1991: 1243). Patricia Hill Collins took this one step further by delineating the concept of a matrix of domination: «how these intersecting oppressions are actually organized» (Hill Collins, 2000: 18). Sudbury has also advocated for the use of intersectionality when writing about imprisoned women through her call for an end to a «unidimensional analyses that provide either a race-bases or a gendered or a class-bases analyses» (Sudbury, 2005: xvii). Any analysis of women in prison should instead «seek to provide localized and specific instances of criminalization, punishment, and resistance, centered on the experiences of women of color and third-world women» (Sudbury, 2005: xvii). This project is a concrete response to this appeal. 
The model below illustrates how these four categories intersected and mediated one another (Mullings \& Wali, 2001) in this particular prison:

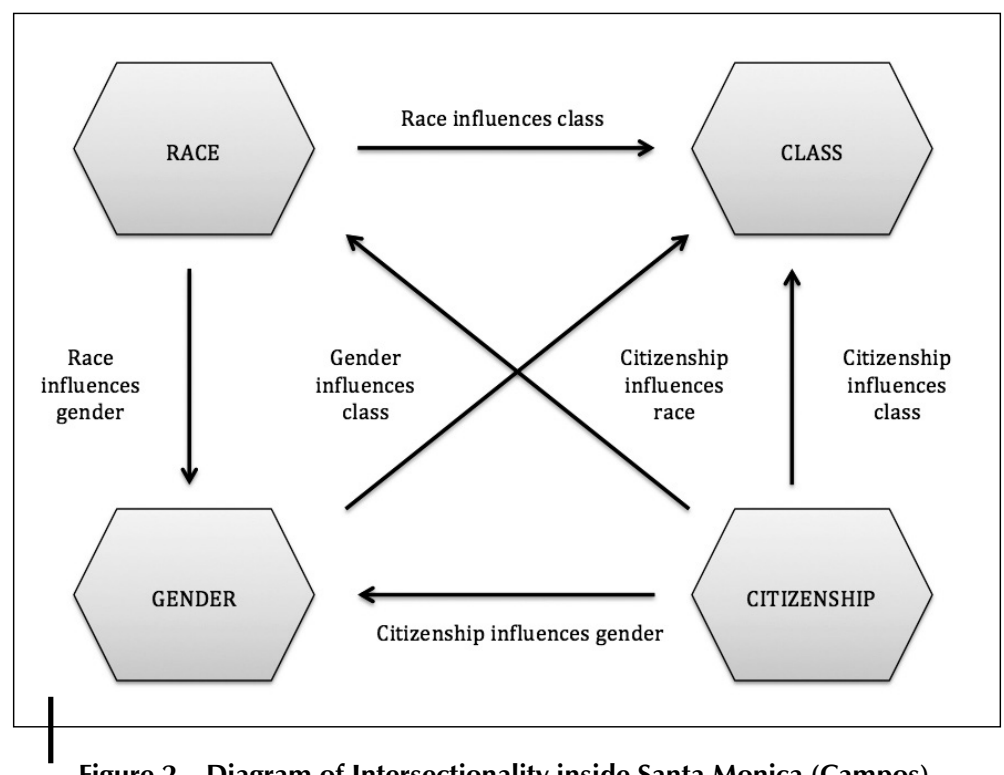

Figure 2 - Diagram of Intersectionality inside Santa Monica (Campos)

This model illustrates how these markers of inequality interacted inside this particular prison. Citizenship influenced how gender, race and class were experienced. Race affected class (in other words, class is raced in Peru). Race also influenced gender (for instance, white women had more access to resources than women of color). Gender influenced class (for example, women experienced poverty in different ways than men). Class (economy) was dependent on the other three variables. The lack of arrows coming out of class is interesting. In the prison everything else affected it, especially citizenship. The framework above is limited in that it excludes other factors that may also have been important in shaping daily life inside Santa Monica such as age and sexuality. In addition, this model is not the only way to understand the convergence of multiple oppressions inside a prison but it is a start in examining the multifarious experiences of incarcerated women.

This study also builds on the growing body of literature on incarcerated women in Spanish-speaking Latin America. Cárdenas (2010), for example, has found that the region's prison systems have become a site for the reproduction and deepening of socioeconomic, gender and ethnic inequality. Although women create strategies to resist and transform the conditions of their incarceration, the penal system reproduces and exacerbates inequality, discrimination and violence towards women (Pontón Cevallos, 2006). Discrimination against female prisoners leads to 
inequality and is the source for social exclusion (Almeda \& Bodeón, 2007). When comparing female incarceration to that of men's in Latin America, various authors have argued that the prison is a social institution that was created to control a primarily male population (Cárdenas, 2010; Pontón Cevallos, 2006; Azaola, 2005; Antony, 2004) and was thus constructed around the needs of men. Women are therefore made invisible within carceral institutions (Azaola, 2005) and they experience discrimination in access to resources (Moragas, 2009; Cevallos, 2006). This reinforces and deepens the various forms of control and vulnerability of this population (Cárdenas, 2010). This article contributes to this literature by analyzing the role of citizenship in the stratification of a female prison and how it interacts with gender and race.

\section{METHODOLOGICAL APPROACH}

This work is based on nine months of ethnographic fieldwork conducted in the Santa Monica prison from 2008 to 2009 with fifty incarcerated women. I also visited the prison for periods of one to two months from 2004 to 2010. I used participant observation as a way to understand daily life inside Santa Monica. This method consisted of me sitting on a bench in the prison's main patio and «hanging out» with several women whom I saw and spoke with regularly during fieldwork. I listened to their conversations, asked questions about the prison, chatted about Santa Monica's daily life, as well as other topics such as food, music, movies, children, dogs, men, and any number of other things. After two months of doing this I finally began to request formal interviews. I conducted participant observation first because this allowed some of the women to get to know me better and to become familiar with my research goals. This contributed to building trust. Privacy was a valued luxury inside the prison and I purposely did not ask for interviews until I felt that at least some of the women there were comfortable with me as a researcher and as a person.

The selection criteria for interviews included participants who 1) were in prison on charges of drug trafficking or drug consumption, 2) were 18 years old or older, 3) had been sentenced or were still waiting for sentencing, 4) were not pregnant. Sampling methods used included snowball sampling, which «asks people who possess specific characteristics to identify others known to them who share those characteristics» (LeCompte \& Schensul, 1999). This method is useful for research with populations that are difficult to reach or when dealing with sensitive questions. After interviewing a participant I asked her if she knew of another woman in the prison who might agree to participate in the study. Convenience sampling, a method that selects from any group readily accessible to the researcher, was also used (Bernard, 1994). I approached different women in the prison, described the project and criteria for participation and gave them my contact information in the event that they would want to participate in the project. With both sampling methods I emphasized the voluntary nature of participating in the study. 
Throughout my fieldwork, I also used life history narratives in order to bring out the sequence of events and to form probable explanations of why and how informants came to work in the drug trade. These evoked the «multiple dimensions of women's lives» (Alcalde, 2010: 6). As women spoke to me about their childhoods, families, relationships, children and work, I was able to piece together a multi-faceted picture of those (Alcalde, 2010: 6) who had worked or were accused of working in the drug trade. Life history narratives helped to elicit basic demographic information and informed me of the general circumstances of the lives of my research subjects (Maher, 1997). Through these narratives, which recorded «information from the informant's perspective from beginning to end» (LeCompte \& Schensul, 1999), I tried to document the nature and conditions of their lives before incarceration and their motivations for undertaking criminalized work (Owen, 1998) or, if they were not involved in this kind of work, how they, nonetheless, came to be imprisoned for it. This gave participants the option of providing only the information they were comfortable giving.

Because of the nature of life history interviews, I asked few leading questions and none of those inquired into the details of their work in the drug trade. This was one way in which to ensure that privacy was respected. As a way to begin the interview I asked participants to tell me about their lives. These interviews lasted about one to two hours and informants could choose to end the interview at any time. In order to help maintain confidentiality, conversations were not audio or video taped, nor did I take any photos of prisoners. All interview notes were hand written by myself only. This paper weaves together segments from my fieldnotes (in italics) with analysis. In this way I hope to maintain the voices of interviewees. In addition, all names have to been changed to protect the privacy of the women who participated in this study.

\section{INSIDE SANTA MONICA: HOW INEQUALITIES BECOME REORGANIZED}

For the first couple of months of my fieldwork in the prison, I listened and watched. Mostly, I listened. Almost always, women sat in groups of at least two. I tried not to interrupt the flow of their conversations with too many questions and instead nodded my head in agreement or disbelief, laughed at jokes, shared coffee and empanadas. I had been prepared to collect information as to how women ended up in the prison and was working my way to asking for formal interviews. But in the conversations that I was privy to, I noticed that much of the talk revolved around money: who had it, who didn't have it, how to get it, who owed who money, the cost of grocery items and bribes, when one was getting money from relatives or a husband. I became attuned to how money shaped much of the daily life inside Santa Monica and began to learn how much citizenship influenced access to this very important resource.

Citizenship intersected with race and gender to reorganize privilege and oppression inside Santa Monica in ways that affected length of sentences, access 
to resources and visits. For example, Linda received her sentence four months after entering Santa Monica. This was a relatively short time period for receiving a sentence and had something to do with Linda ability's to pay for a lawyer to hasten her way through the court system: «I was given nine years but I didn't accept it», she says. She had her lawyer appeal her sentence and was given six years. During my fieldwork, I encountered women who waited from six months to a year to be sentenced. Out of 769 women in Santa Monica, only 280 had been sentenced. The rest are listed as «processed» (INPE, 2012). Knowing one's sentence was important because it gave them an endpoint to their incarceration, it was a goal to work towards. Inequality among women in the prison was therefore expressed through their ability to pay for lawyers and the time they had to wait to be sentenced. Thus, some foreign prisoners were able to hasten their exit from Santa Monica: "Linda says that she was set to leave the prison in four months. "If you pay good money, your papers go fast", she explains. She will ask her husband to send her money so that she can move her papers faster».

Citizenship influenced remittances from familial networks abroad; played a role in partnerships with men; determined how dependent one became on charity and church groups; and finally, it defined the extent to which one had to 'hustle' inside the prison. All of this varied according to the position of one's country of citizenship in the global political economy. Prisoners with legal ties to Northern countries were in most cases better well off than those who were citizens of Southern nations. This is however not an attempt to naturalize the North/South distinction. Each nation-state has its own complex class system. But this division among foreign prisoners illustrates the powerful effects of transnational inequities as a result of colonialism and global economic processes such as capitalism.

Linda tells me that she and a friend in the prison argued and after they fought because her ex friend began to put her debts in Linda's name. She found out about this when she went to the prison store one day and was told that she owed 500 soles (nearly $\$ 170$ dollars). «l argued with women in here about this and that's why I've been in solitary confinement twice», she tells me. Linda tells me that "solitary confinement is ugly and dirty». There was no electric light in the room but she was given a light. She boasts that she brought everything with her into calabozo, including contraband - cigarettes, food from the food vendors in the prison, an mp3 player. She lends or gives money to the guards so that the rules are bent for her. "If you have money», she tells me, «then everything is good».

In Linda's case, money sent to her by her husband (who owned several businesses through his own previous work in the drug trade) provided her a certain level of comfort inside the prison. Her work as an international transporter of cocaine gave her access to money that she used to bribe the guards. Access to resources didn't completely protect her — she was still put in calabozo- but she was able to bend the rules and more importantly for her, move her release paperwork through the courts faster through bribes and through her ability to pay for a lawyer. Furthermore, she was able to pay her attorney to successfully appeal the court for a shorter sentence. Pro-bono attorneys were available to incarcerated women 
through the country's Ministry of Justice but I was told on several occasions that they still expected some kind of payment for their services and that the process of dealing with one was very slow.

Ada's status as a Spanish citizen intersected with gender to shape her access to resources, in this case, calling cards: She is writing a letter to a man at Lurigancho, one of the male prisons in Lima. «Making phone calls is my vice», she tells me. «You meet men to write to through other women inside. These women have husbands, boyfriends in other prisons. I have a lot of pen pals in the other male prisons. They send me phone cards so that I can call them». She gets a lot of letters on Sundays. "When I'm feeling down, I write letters and I vent my feelings. The next day I'll call these men».

Although not officially allowed, many male prisoners had cell phones. Reinforcement of the no cell phone rule was lax primarily due to the bribes given to guards to «look the other way». The control of cell phones was much stricter in Santa Monica —rooms were searched for contraband-. If a prisoner was caught with a cell phone, she could be written up or put in solitary confinement. Ada called the cell phones of her male pen pals from the pay phones in Santa Monica. That she received phone cards from these men is important because these calls cost money, a scarce resource inside the prison. Male prisoners may have seen her as a «catch» because of her Spanish citizenship. This status enabled her to receive certain gifts such as phone cards, a gendered way of how inequality among women in the prison was expressed. At the same, however, Ada felt that she more at risk for being manipulated by Peruvian men: Ada had several boyfriends who visited her or wrote to her from the other male prisons. «Different men may come for one woman on Saturday's. It's all about money or things». She continues: «Men look for work». She entered into a relationship with the nephew of a fellow prisoner. «I ordered a package from Spain to be delivered to his house so that he could bring it to me but he never brought the package, which included money for me. He always claimed that he was broken. I broke up with him because I thought that he was using me». Ada's citizenship and gender intersected to shape her access to valued goods. The division between foreigners and Peruvian prisoners was also represented on visiting days.

Male visiting day was a time to show off, to maintain a relationship or begin a new one. It was a chance to flirt, maybe be treated to a meal, and receive money or other personal items. Many women dressed up in their best and most revealing clothes, put on makeup and had their hair done (Fridays were busy days in the hair salon). Men and women could sit close to one another, hold hands and steal a kiss when the guards weren't looking. Foreign prisoners, especially those from North American and European countries, were often «set up» on Saturdays by other prisoners, friends or acquaintances outside or sometimes even their lawyer. Their status as foreigners from North America or Europe made them desirable mates for two reasons. First, their American, Canadian or Spanish citizenship offered the possibility to a Peruvian husband of obtaining a visa from these countries. Secondly, their access to dollars and euros could serve as another source of income for Peruvian boyfriends. Ada 
spoke to these two themes when she described her relationship with a Peruvian man. Male visiting days contributed to the friction between foreign and Peruvian women. Cynthia (Peruvian) offered a critique of this dynamic in her comments.

On Saturday's they wear skimpy clothing and walk past the Peruvian men and cause problems between the Peruvian couples because the men look. They also sit down and flirt with the men and ask them for their phone numbers. They do this in order to feel exciting and better than the other women.

Some foreigners played up their sexuality on male visiting days. They also emphasized their status as foreigners. In this way they set themselves apart from the Peruvian prisoners. In Cynthia's opinion they were trying to demonstrate that they were «better than the other women», in other words better than Peruvian women. Some foreign prisoners therefore manipulated gender and citizenship for male attention. But this particular form of manipulation was not available to all foreigners as some nationalities and races were perceived to be more desirable than others.

Visits were an area of prison life that was affected by citizenship. They were important for all incarcerated woman, no matter what her citizenship, class and race. Visitors may have brought with them items such as food. No fruits or vegetables were supplied to the women in Santa Monica and they complained to me that the meals given to them by the prison were of low quality and poor taste. There were food vendors in the prison, prisoners who had set up their own stalls and cooked meals that they sold for a fee. But for those who could not afford these personal services their only options were the prison food and groceries brought to them by visita. Often mothers of incarcerated women (who made up the majority of visitors on female visiting day) would bring entire meals in carefully packed Tupperware dishes. Visita would also bring toiletries, blankets for the cold weather, clothes, newspapers, magazines, cigarettes and some money. Ada demonstrates how visita is affected by the intersection of gender and citizenship: «There are a lot of Peruvian women inside who don't get family visits. Months go by and they don't come and when they do, they don't bring anything. Last Saturday a Peruvian man brought me things and I think that's why some of the Peruvian women are jealous of me», Ada says.

Peruvian women typically had some relatives who lived in Lima and would make the trip to Santa Monica on visiting days, some coming regularly, others only occasionally because of work or not having enough money to pay for the transportation to the prison. Foreign women of course did not have family members living near the prison. Visita for them included church members (for the foreign women who joined one of the church groups that visited the prison), Peruvian friends or boyfriends and individuals they paid to make deliveries. These were people — male and female- who did a number of jobs for women in Santa Monica. Among these were: purchasing desired items (like groceries) and delivering them on visiting day; bringing emails and letters from friends and relatives back home; and/or delivering letters from men in the surrounding male prisons. For many of the foreign women, these individuals became lifelines to the world outside Santa Monica. Visita, particularly friends and family members, were welcomed for their 
emotional value and were also a break from the boredom of incarceration. Ada received visits and gifts from men on the outside, something that was highly valued there. Peruvian women in Santa Monica were generally non-white and as Ada explains, some didn't receive any visita. A woman without any visitors was to be pitied as she was left to her own devices for surviving her incarceration. As one Peruvian woman put it: "Visita lifts your spirits, you get happy when your name is called (announcing that you have a visitor). It also helps financially».

Leslie did not have access to the money that Linda and Ada had. Her visitors were fellow church members and she depended on them to receive much-needed goods. She illustrates the misalignments that existed in Santa Monica as a result of the inequalities between nation-states. She spoke about her life inside the prison: "I understand myself now and the Lord is guiding me and helping me». She had tuberculosis and spent four months in the prison clinic. «The lord healed me». I ask her how she survives economically. «My bible study group has helped me. They are evangelists and have helped me a lot. They would buy me milk, toilet paper, other things while I was ill. I don't have help from my family. They know that I am in Santa Monica but they don't want to help. Find your own way out of there, they told me». Leslie has been in Santa Monica for one year and two months.

As a citizen of a non-Peruvian nation, she had no relatives or friends nearby who could bring her food and other items like medicine. In addition, relatives «back home» in countries of the South were less likely to have the income to do this from a distance; for example, send remittances or care packages to their incarcerated family members in Peru. In addition, Leslie, unlike Ada, didn't receive a stipend from her embassy. At the time of my fieldwork, the Spanish embassy provided a monthly stipend for their citizens. As a holder of a Malaysian passport (as opposed to a North American or European one), she was also not courted by Peruvian men and more likely to receive personal gifts. Peruvians who desire to emigrate do not typically think of Malaysia as a possible destination for work. She was also not able to work inside the prison because of her illness. Leslie's only outside support, therefore, was that of a church group she joined for spiritual comfort. Linda on the other hand, received financial support from her husband.

Paloma, unlike Linda and Ada, struggled to piece together an income for herself. She was also financially responsible for her daughter: «When I was arrested I realized that I had lost everything. I found out I was pregnant when I got to Santa Monica». Her daughter lives inside the prison and is one year and five months old. «l am always working in the nursery in order to earn two, three soles per day. I do clean up. I also clean the hallway and the bathroom on my floor. My embassy doesn't help me with anything and I don 't have any visits. My son's father sends his mother money for our son and helps with his schooling. My family can't send me money». She tells me the things she needs to pay for: diapers, baby shoes, baby clothes and milk. «Sometimes you clean for someone and they don't pay you», she tells me.

Paloma illustrates how global inequalities manifested themselves in Santa Monica. She was a foreigner, but of a much different kind than those from North American and European countries. Bolivia's location in the global political economy affected 
her in several different ways. She did not receive money from relatives back home because they could not afford to do so. They were also too far away to visit her and bring items like food and clothes. She provided cleaning services for other women in the prison and for the prison itself in order to make money to buy things for herself and her child. Her Bolivian citizenship impacted her options for survival inside the prison.

Citizenship also intersected with race inside Santa Monica. Sanjek's claim that «race is the framework of ranked categories segmenting the human population that was developed by Western Europeans following their global expansion beginning in the 1400s» (Sanjek, 1994: 1) is useful in this study because it provides a starting point for conceptualizing race in a Peruvian prison that holds both Peruvians and foreign women. This country's racial hierarchy was reflected in Santa Monica through a prison population made up overwhelmingly of non-white women. In addition, foreign prisoners brought with them their own interpretations and meanings of race. Therefore, different beliefs and attitudes around this structure of ranked categories based on culturally constructed racialized markers such as skin color and other physical features existed in this one single space. Race as a social concept arranged prisoners within a hierarchy that in general privileged white women over non-whites. Although they changed one another during moments of interaction, ultimately citizenship and race did not become completely different constructs. Ada's comments on race shows how these inequalities change at the point intersection and yet remain the same: «My parents kicked me out of their home and they didn't speak to me or give me money because my husband was African». I ask her if she thinks there is racism in Santa Monica. «There is racism against the Spanish women in the prison. I think that there is racism against blacks and that there is a stereotype that Africans are the big drug traffickers». I ask her why was she never caught with drugs on her previous trips. «I dressed up and other people like the airport staff were bribed».

Ada uses racism in two different ways: racism based on country of citizenship and then again towards a historically racialized group. Many of the foreign prisoners perceived that the discrimination they experienced in Santa Monica was a result of citizenship status rather than racialized phenotypic markers. Ada was aware that her parents had been unable to accept her African husband because of their prejudice towards this population. But she also believed that she was the object of racism from Peruvians inside the prison because of her Spanish citizenship. In addition, when she was working in the TCCC, she had used her «whiteness» and blond hair to avoid detection at airports when she transported drugs. Patti (Spanish) articulated this intersection between race and citizenship very clearly: I ask Patti about racism in the prison. She says:

It does exist but it's based more on class. For example, I might be discriminated against because I'm Spanish and the preconceptions about Spanish women, Nelly is Black but because she's a foreigner (North American) she's on a higher class than other Peruvian women. Here racism isn't based on the color of your skin but how much money you have. 
Patti's comments drew a direct relationship between citizenship and monetary wealth. How much money one had in Santa Monica largely depended on one's country of citizenship. As mentioned earlier, Spanish women were among the wealthiest groups in the prison and negative assumptions about them were numerous. For example, other women in the prison might have assumed that Patti was a drug consumer because of the stereotype of the Spanish women as drug addicts. Nelly's racial status as a Black woman might have been subordinate to other racial statuses in this Peruvian racial hierarchy but being a citizen of a North American country automatically placed her in a «higher class» above Peruvian prisoners. Race, class and citizenship become conflated and used interchangeably. But what is significant in this relationship is Nelly's citizenship and Patti's status as a Spanish national. Inequalities among nation states in the global political economy were reflected in Patti's comments. These inequalities made a difference in how race and class were understood by foreign women.

These social categories intersected in different ways for Peruvian prisoners. They were also aware of race, such as how a woman's whiteness worked to her benefit. In addition, they perceived foreign American and European prisoners as having more privileges than themselves because of their American or European status. Some Peruvian women pointed out to me that foreign women spent less time inside Santa Monica, even in cases when they were carrying more drugs than themselves:

Maria is Peruvian and is inside with her two adult daughters and their infants. The police came to her house and found a bag containing one kilo of marijuana in her son's bedroom. Everyone in the house was incarcerated. She complains about the unfairness of their sentence, and compares her case to Paula's who is walking past the phones at that moment in our line of vision. Paula is Dutch, white and blond. Maria says that Paula was caught with several kilos of cocaine and got three to seven years along with her husband. She tells me that the judge fell in love with her pretty looks and took it easy on her. Maria was sentenced to ten years.

When Maria, a non-white Peruvian, talked about Paula's «pretty looks», she was referring to her whiteness and the value that this has for women in a country with a racialized hierarchy. Maria explained her sentence being longer than Paula's as racial privilege. The fact that relationships between women in the prison were affected by race led to daily negotiations and interpretations. Ada for example was well aware of the unequal relationships that existed between women in Santa Monica and the position of foreign women within the prison hierarchy. Peruvian women saw opportunities for accessing resources through relationships with foreign women and rumors would spread as to whom were «using» whom: Ada tells me that she doesn't think much of Peruvians. «Everything is problems here», she says. «There is a lot of gossip, a lot of drugs. Peruvians do drugs including cocaine. The Spanish women get money and the Peruvian women want to live off of other women». Other women were angry with her because she got special phone privileges one day. 
The perception that foreign women benefit from their economic status and race further exacerbated tensions between Peruvian and foreign prisoners, especially those from North America and Europe who were more likely to be white. For example, Peruvians perceived these foreigners as lazy. «The foreign women don't want to do anything», Rosario told me one day. "So they pay other women to do it for them, like their laundry or cleaning. They give us work». Most of the incarcerated foreign women from North America and would be considered working class/working poor in their own countries. But because of their status as citizens of Northern nations, they often occupied a privileged position inside the prison. Many did not have to work for economic survival. If they did work, it was probably in order to be eligible for a sentence reduction, receive a report for good behavior or even to alleviate the monotony of prison life:

I am sitting with Dana (South African) and Jean (South African). Dana will be starting one of the job workshops in August. "I'm looking forward to it, I want to keep busy. All you do here is talk until you run out of things to say. You know all about each other and then there's nothing to talk about or you keep saying the same things over and over». Jean exclaims: «Like 'I want to leave'!».

Dana and Jean received money from their networks in South Africa and did not have to depend on their labor in Santa Monica for income. For Dana, working meant a temporary release from the tedium of daily life in the prison. These two women belonged to the group of prisoners who were foreigners that received money from relatives back home. This allowed them some privileges in contrast to Peruvian women and foreign women who did not have this access to resources. But the dullness of life inside the prison affected even this group of privileged women.

In addition, Black non-Peruvian women from North American and European countries still experienced racism inside Santa Monica despite their more economically privileged status. This was an example of how the relationships among incarcerated women in Santa Monica were raced: Lily, Tanya and Nelly are Black North American and Western European citizens. We are talking about racism in the prison. They complain of being called 'nigger' every day. When they are called «negra» they take it as being called nigger. «At first», Jenny says, «l tried to fight against it (the racism) but I've given up». Nelly says something similar. After a while they stop trying to fight it. They tell me that not a day goes by that someone doesn't say something racist to them.

The contradiction is that they were also among the wealthiest women in the prison. Nelly hired someone to wash her clothes, make her bed and she didn't work. Lily's release paperwork moved quickly because she had bribed prison staff. Sometimes citizenship, class and race conflicted with one another as Nelly demonstrated in her comments about Alicia: Alicia (Black Panamanian) steps away from Nelly (Black American) and me to buy an empanada. Nelly and I start chatting. Alicia has asked her to bring her along to Miami when they are released. Miami is Nelly's hometown. Nelly tells me that she started teasing Alicia: «l asked her - where can I take you in Miami? Because Alicia is rough. I told her that I would take her to the 
zoo and she got MAD». Nelly laughs at the memory. She turns a little serious and says, «Alicia is okay for hanging out inside but outside...?». Nelly shakes her head. "She is too rough around the edges for my taste». Alicia comes back at this point.

When Nelly said that she would take Alicia to the zoo, she meant that Alicia belonged in a zoo, that she would leave her there. Both women shared certain identity markers as a result of their common positionalities around race, gender and citizenship status and life stages: they were Black women, in their twenties, foreigners, and they both spoke English. They were also both incarcerated. But for Nelly the similarities ended there - Alicia came from a poor neighborhood in a Central American country that contrasted with Nelly's solid working class/ middle class background in the United States. Nelly was making a class distinction between herself and Alicia, one that superseded race and gender. Nelly's choice of a zoo was even more poignant because of the historical association of Blacks with animalistic features and emotions. In fact, Alicia later shared with me that Nelly had once been called a monkey by one of the Peruvian prisoners and that she has subsequently «beat her up». Ties between women based on race would therefore go only so far, particularly if there were other differences such as class that cut across relationships among prisoners.

\section{DISCUSSION}

Tensions therefore existed among foreigners and between this population and Peruvian women. This reflected the unequal social relations that existed within Santa Monica. The TCCC, as it travels back and forth across the Atlantic moving people and product, disposes of its female workers into the prison once they are no longer needed. In addition, the presence and intensification of the war on drugs in Peru propels low-level workers of the cocaine chain to incarceration. These two factors explain the presence of women from disparate countries in this one prison. But not all foreign prisoners in Santa Monica were the same. The clearest division among foreign women was that of citizenship as it related to the position of her country in the larger global political economy. Being a citizen of a nation that was not European or North American had acute implications for access to resources and relationships formed inside and outside the prison. Privilege and oppression were affected by one's citizenship status and it intersected with gender and race inside Santa Monica. These points of interaction are important because they reinforced and reorganized divisions among incarcerated women.

Linda, Ada, Leslie, Paloma are representative of many of the foreign women in Santa Monica. Non-Peruvian prisoners were incarcerated on charges of drug trafficking. They were citizens of different nation-states. They were Black, white, mestiza, biracial, mixed, and a multitude of categories in between. Many were mothers. All were transporters of cocaine. These women had worked transnationally and several had no idea that they were smuggling. Many had a history of financial struggle prior to working in the TCCC. Furthermore, women competed for access to resources and their citizenship status affected this competition. For example, 
Linda and Ada had more access to resources than Leslie and Paloma. Formal connections to a particular nation-state also had an effect on their experience incarceration and relationships with other prisoners. These were expressed in ways that were gendered and racialized. They also reflected inequalities based on the role of nations in the licit global economy. Leslie and Paloma were both foreigners but of a very different kind than Linda and Ada. Both were women of color and citizens of Southern nations. They also struggled to make ends meet while serving their sentences. Paloma looked for work in Santa Monica's informal job market and Leslie depended largely on the charity of her church. Relationships with men during incarceration became an important source of emotional and economic support and women from Northern countries were more likely to begin new heterosexual relationships that included gifts and other goods.

The women included in this paper illustrate how citizenship contributes to shaping the stratification system that exists in this prison. Santa Monica is a site of transnational social relations in that citizenship mattered with regards to who got what and how often. Race, class, gender and citizenship mutually shape one another at points of intersection. The options presented to Paloma, Leslie, Ada and Linda during incarceration were formed at these moments of interaction. They did the best they could with the choices presented to them as they struggled to survive their incarceration.

\section{References Cited}

ALCALDE, M. C., 2010 - The Woman in the Violence: Gender, Poverty and Resistance in Peru, 264 pp.; Nashville: Vanderbilt University Press.

ALMEDA, E. \& BODELÓN, E., 2007 - Presentación. In: Mujeres y Castigo: Un Enfoque SocioJurídico y de Género (E. Almeda \& E. Bodelon, eds.): 13-23; Madrid: Dykinson.

ANTONY GARCÍA, C., 2004 - Panorama de la Situación de las Mujeres Privadas de Libertad en América Latina Desde una Perspectiva de Género. In: Violencia Contra las Mujeres Privadas de Libertad en América Latina: 75-88; Washington, D. C.: Due Process of Law Foundation; Comisión de Derechos Humanos del Distrito Federal; Comisión Mexicana de Defensa y Promoción de los Derechos Humanos.

AZAOLA G., E., 2005 - Las Mujeres en el Sistema de Justicia Penal y la Antropología a la que Adhiero. Cuadernos de Antropología Social, 22: 11-26.

BERNARD, H. R., 1994 - Research Methods in Anthropology: Qualitative and Quantitative Approaches, 588 pp.; Walnut Creek, CA: AltaMira Press.

CÁRDENAS, A., 2010 - Mujeres y Cárcel: Diagnóstico de las Necesidades de Grupos Vulnerables en Prisión, 117 pp.; Santiago de Chile: Universidad Diego PortalesICSO.

CRENSHAW, K., 1991 - Mapping the Margins: Intersectionality, Identity Politics, and Violence against Women of Color. Stanford Law Review 43 (6): 1241-1299. 
HILL COLLINS, P., 2000 - Black Feminist Thought: Knowledge, Consciousness, and the Politics of Empowerment, 335 pp.; New York: Routledge.

INSTITUTO NACIONAL PENITENCIARIO (INPE), 2010 - Informe Estadístico Diciembre 2010, 2 pp.; Lima: Oficina de Planeamiento y Presupuesto del Instituto Nacional Penitenciario.

INSTITUTO NACIONAL PENITENCIARIO (INPE), 2012 - Informe Estadístico Diciembre 2012, 84 pp.; Lima: Oficina de Planeamiento y Presupuesto del Instituto Nacional Penitenciario.

KIPNIS, A., 2004 - Anthropology and the Theorisation of Citizenship. The Asia Pacific Journal of Anthropology 5 (3): 257-278.

LeCOMPTE, M. \& SCHENSUL, J. J., 1999 - Designing \& Conducting Ethnographic Research, 220 pp.; Walnut Creek: AltaMira Press.

MAHER, L., 1997 - Sexed Work: Gender, Race and Resistance in a Brooklyn Drug Market, 279 pp.; Oxford, New York: Clarendon Press.

McCRONE, D. \& KIELY, R., 2000 - Nationalism and Citizenship. Sociology, 34 (1):19-34.

MORAGAS, M., 2009 - Mujeres, Derecho Penal y Cárcel: Otra Forma de Violencia de Género. Panorama/Informativo Mujer Digital; Asunción: Centro de Documentación y Estudios. Disponible en: http://www.informativomujer.org.py/?p=326

MULLINGS, L. \& WALI, A., 2001 - Stress and Resilience: The Social Context of Reproduction in Central Harlem, 210 pp.; New York: Kluwer Academic/Plenum Publishers.

OWEN, B. A., 1998 - «In the Mix»: Struggle and Survival in a Women's Prison, 219 pp.; Albany: State University of New York Press.

PONTÓN CEVALLOS, J., 2006 - Mujeres que Cruzaron la Línea: Vida Cotidiana en el Encierro, 58 pp.; Quito: FLASCO Ecuador.

SANJEK, R., 1994 - The Enduring Inequalities of Race. In: Race (S. Gregory \& R. Sanjek, eds.): 1-17; New Brunswick, N. J.: Rutgers University Press.

SUDBURY, J., 2005 - Introduction: Feminist Critiques, Transnational Landscapes, Abolitionist Visions. In: Global Lockdown: Race, Gender and the Prison-Industrial Complex (J. Sudbury, ed.): xi-xxviii; New York: Routledge.

WALBY, S., ARMSTRONG, J. \& STRID, S., 2012 - Intersectionality: Multiple Inequalities in Social Theory. Sociology 46 (2): 224-240.

WILSON, S. \& ZAMBRANO, M., 1994 - Cocaine, Commodity Chains, and Drug Politics: A Transnational Approach. In: Commodity Chains and Global Capitalism (G. Gereffi \& M. Korzeniewicz, eds.): 297-313; Westport: Greenwood Press. 